Volume 10 Issue 1, January-March 2016: pp. 1-220. Copyright (c) 2015-2016 FIAT JUSTISIA. Faculty of Law, Lampung University, Bandarlampung, Lampung, Indonesia. ISSN: 1978-5186 | e-ISSN: 2477-6238.

Open Access: http://jurnal.fh.unila.ac.id/index.php/fiat

Fiat Justisia is licensed under a Creative Commons Attribution 4.0 International License, which permits unrestricted use, distribution, and reproduction in any medium, provided the original work is properly cited.
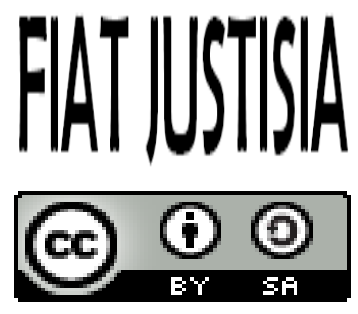

\title{
KEBIJAKAN HUKUM PIDANA TERHADAP PEMBATASAN KEWENANGAN PENYIDIKAN TERHADAP NOTARIS (Undang-Undang Nomor 2 Tahun 2014 tentang Jabatan Notaris)
}

\section{Criminal Law Policy to Limitation Authority Investigations on Notary (The Law Number 2 of 2014 on Notary Office)}

\author{
Desi Indriani \\ PT. Great Giant Foods Lampung Tengah \\ email: desiindriani0@gmail.com
}

\begin{abstract}
The criminal law policy of the authority restriction in investigation against the notary is at the stage of policy formulation of the law provided authority Honorary Council of Notaries in the proceedings against the notary is to give consent to the investigator, prosecutor or judge to take copies Minuta Deed and / or letters attached to Minuta Deed or the Protocol Notary Notaries in storage. The legal implications for restricting the authority in the investigation of the Notary of the proceedings for the notary is not in accordance with equality of citizens before the law should not discriminate between the treatments of nationals who commit criminal acts. Additionally, Notary Honorary Council approval is also contrary to the principle of independence in the judicial process.
\end{abstract}

Keywords: Policy, Restriction Authority, Notary

\begin{abstract}
Abstrak
Kebijakan hukum pidana dari pembatasan kewenangan dalam penyidikan terhadap notaris adalah pada tahap perumusan kebijakan hukum yang tersedia Kehormatan Dewan kewenangan Notaris dalam proses hukum terhadap notaris adalah untuk memberikan persetujuan kepada penyidik, jaksa atau hakim untuk mengambil salinan Akta Minuta dan / atau huruf yang melekat pada Akta Notaris Minuta atau Protokol Notaris dalam
\end{abstract}


penyimpanan. Implikasi hukum untuk membatasi kewenangan dalam penyelidikan Notaris dari proses untuk notaris tidak sesuai dengan kesetaraan warga negara di hadapan hukum seharusnya tidak membedakan antara perawatan dari warga negara yang melakukan tindak pidana. Selain itu, persetujuan Dewan Kehormatan Notaris juga bertentangan dengan prinsip kemerdekaan dalam proses peradilan.

\section{Kata Kunci: Kebijakan, Kewenangan Pembatasan, Notaris}

\section{A. Pendahuluan}

Notaris pada dasarnya merupakan pejabat umum yang memberikan kepastian hukum kepada masyarakat melalui akta otentik yang dibuatnya. Kedudukan notaris sebagai pejabat umum sangat dibutuhkan oleh masyarakat dewasa ini, sebab masyarakat tidak lagi mengandalkan perjanjian yang berdasarkan atas kepercayaan satu sama lain seperti yang mereka kenal dulu. Setiap perjanjian yang dilakukan oleh masyarakat mengarah kepada notaris sebagai sarana keabsahan perjanjian yang mereka lakukan, sehingga kedudukan notaris menjadi semakin penting. ${ }^{1}$

Keberadaan notaris menurut peraturan perundang-undangan mengenai notaris pun mengalami perkembangan. Perubahan Undang-Undang Nomor 30 Tahun 2004 tentang Jabatan Notaris menjadi Undang-Undang Nomor 2 Tahun 2014 tentang Jabatan Notaris (selanjutnya ditulis UUJN), hal ini didasarkan pada upaya mewujudkan jaminan kepastian hukum, ketertiban dan perlindungan hukum yang berintikan kebenaran dan keadilan.

Selain itu dalam menjalankan jabatannya, notaris harus dapat bersikap profesional dengan dilandasi kepribadian yang luhur dengan senantiasa melaksanakan undang-undang sekaligus menjunjung tinggi kode etik profesinya yaitu Kode Etik Notaris. ${ }^{2}$

Notaris dalam menjalankan tugasnya sebagai pejabat umum untuk membuat akta otentik diawasi oleh Komisi Majelis Pengawas yang terdiri dari Majelis Pengawas Daerah, Majelis Pengawas Wilayah dan Majelis Pengawas Pusat dengan tujuan agar Peraturan Jabatan Notaris dan Kode Etik Notaris dapat dilaksanakan dengan baik. Notaris dalam menjalankan tugasnya selalu memperhatikan syarat-syatat atau ketentuan-ketentuan yang ditetapkan oleh Undang-undang demi terjaminnya kepastian hukum bagi pihak-pihak yang membuat perjanjian. Pengawasan yang dilakukan terhadap notaris sangat beralasan karena notaris merupakan pejabat yang memberikan

\footnotetext{
${ }^{1}$ Saputro, Anke Dwi. (Ed), (2009). Jati Diri Notaris Indonesia, Dulu, Sekarang, dan Di Masa Mendatang. Jakarta: Gramedia Pustaka, p. 33.

${ }^{2}$ Utama, Shidarta. (2006). Moralitas Profesi Hukum. Bandung: Refika Aditama, p. 127.
} 
jasanya kepada masyarakat dan memberikan penjelasan mengenai peraturan perundang-undangan yang berlaku.

Mengingat peranan dan kewenangan Notaris sangat penting bagi masyarakat, maka perilaku dan perbuatan Notaris dalam menjalankan jabatan profesinya, rentan terhadap penyalahgunaan yang dapat merugikan masyarakat, sehingga lembaga pembinaan dan pengawasan terhadap Notaris perlu diefektifkan. Ketentuan yang mengatur Majelis Pengawasan dalam Undang-Undang Nomor 30 Tahun 2004 menjadi Undang-Undang Nomor 2 Tahun 2014 tentang Jabatan Notaris (selanjutnya ditulis UUJN), merupakan salah satu upaya untuk mengantisipasi kelemahan dan kekurangan dalam sistem pengawasan terhadap Notaris, sehingga diharapkan dalam menjalankan profesi jabatannya, Notaris dapat lebih meningkatkan kualitas pelayanan kepada masyarakat.

Notaris bertugas membuat minuta (akta otentik) sebagai dokumen negara, dan dalam hal ini berkedudukan sebagai pejabat umum. Pejabat umum adalah pejabat yang diangkat dan diberhentikan oleh kekuasaan umum (pemerintah) dan diberi wewenang serta kewajiban untuk melayani publik dalam hal-hal tertentu, karena ikut melaksanakan kewibawaan pemerintah. Secara umum dapat dikatakan Notaris adalah satu-satunya pejabat umum yang memiliki kewenangan berdasarkan undang-undang yang cukup besar dalam membuat hampir seluruh akta otentik. ${ }^{3}$

Notaris dalam menjalankan jabatannya Notaris harus dapat bersikap profesional dengan dilandasi kepribadian yang luhur dengan senantiasa melaksanakan tugasnya sesuai peraturan perundang-undangan yang berlaku sekaligus menjunjung tinggi kode etik profesi Notaris sebagai rambu yang harus ditaati. Notaris perlu memperhatikan apa yang disebut sebagai perilaku profesi yang memiliki unsur-unsur sebagai berikut:

1. Memiliki integritas moral yang mantap

2. Harus jujur terhadap klien maupun diri sendiri (kejujuran intelektual)

3. Sadar akan batas-batas kewenangannya

4. Tidak semata-mata berdasarkan pertimbangan uang. ${ }^{4}$

Dalam rangka mencapai tujuan hidup itulah, hukum kemudian diciptakan. Meski penuh dengan fregmentasi dan pertentangan, keseimbangan dalam masyarakat harus dicapai. Salah satunya cara, adalah dengan mengakomodasi dua hal yang sebetulnya saling berseberangan atau bertentangan satu sama lain. ${ }^{5}$ Suatu konsep yang berhubungan dengan

\footnotetext{
${ }^{3}$ Adjie, Habib. (2009). Hukum Notaris Indonesia.. Bandung: Refika Aditama, p. 6.

${ }^{4}$ Setiawan, Wawan. (2004). "Sikap Profesionalisme Notaris dalam Pembuatan Akta Otentik", Media Notariat, Edisi Mei-Juni 2004, p. 25.

5 Zainal Arifin Mochtar, (2015), Antinomi dalam Peraturan Perundang-Undangan di Indonesia, Halrev Journal of Law, 1(3): 321.
} 
konsep kewajiban hukum adalah konsep tanggung jawab hukum, dalam arti bertanggung jawab atas sanksi yang dikenakan atas perbuatannya yang bertentangan dengan hukum. Dalam tanggung jawab terkandung pengertian penyebab tanggung jawab dapat dilakukan secara langsung ataupun secara tidak langsung dalam hal dilakukan oleh orang lain, tetapi di bawah kekuasaannya atau pengawasannya.

Konsekuensinya adalah apabila Notaris terbukti melakukan pelanggaran terhadap ketentuan yang ada dalam UUJN, Notaris yang bersangkutan akan terkena sanksi sesuai dengan jenis pelanggaran yang telah dilakukan menurut UUJN. Pengawasan terhadap Notaris dilakukan oleh Menteri dengan membentuk Majelis Pengawas yang berjumlah 9 (sembilan) orang yang terdiri atas unsur:

1. Pemerintah sebanyak 3 (tiga) orang;

2. Organisasi notaris sebanyak 3 (tiga) orang;

3. Ahli/akademisi sebanyak 3 (tiga) orang;

Sampai saat berlakunya UUJN di Indonesia masih terdapat organisasi Notaris yang mempunyai Kode Etik dan diakui oleh pemerintah adalah Ikatan Notaris Indonesia (INI), merupakan suatu organisasi profesi Notaris yang mempunyai kode etik yang ditetapkan dan disahkan oleh Kongres INI. Kongres INI pertama diadakan di Surabaya Tahun 1974 dan kemudian diubah dan disusun kembali dalam Kongres XIII yang diadakan tahun 1981 di Bandung. Selanjutnya Kode Etik Notaris telah disempurnakan melalui Kongres Luar Biasa Ikatan Notaris Indonesia (INI) di Bandung tanggal 29 Januari $2005 .{ }^{6}$

Ikatan Notaris Indonesia (INI) menurut Pasal 1 Kode Etik Ikatan Notaris Indonesia merupakan perkumpulan organisasi bagi para Notaris mempunyai peranan yang sangat penting dalam penegakkan pelaksanaan kode etik profesi bagi Notaris. Kode etik adalah seluruh kaidah moral yang ditentukan oleh Perkumpulan Ikatan Notaris Indonesia yang selanjutnya akan disebut "Perkumpulan" berdasar keputusan Kongres Perkumpulan dan/atau yang ditentukan oleh dan diatur dalam peraturan perundangundangan yang mengatur tentang hal itu dan yang berlaku bagi serta wajib ditaati oleh setiap dan semua anggota perkumpulan dan semua orang yang menjalankan tugas jabatan sebagai Notaris, termasuk di dalamnya para Pejabat Sementara Notaris, Notaris Pengganti dan Notaris Pengganti Khusus. $^{7}$

Pasal 7 Kode Etik Ikatan Notaris Indonesia menjelaskan bahwa pengawasan atas pelaksanaan kode etik itu dilakukan dengan cara sebagai berikut:

\footnotetext{
${ }^{6}$ Saputro, Anke Dwi. (ed), Op.Cit., p. 168.

${ }^{7}$ Ikatan Notaris Indonesia, (2005), Kode Etik Hasil Kongres Ikatan Notaris Indonesia (INI) Tanggal 27 Januari 2005, Bandung. p. 2.
} 
1. Pada tingkat pertama oleh Pengurus Daerah Ikatan Notaris Indonesia dan Dewan Kehormatan Daerah;

2. Pada tingkat banding oleh Pengurus Wilayah Ikatan Notaris Indonesia dan Dewan Kehormatan Wilayah;

3. Pada tingkat terakhir oleh Pengurus Pusat Ikatan Notaris Indonesia dan Dewan Kehormatan Pusat.

Adanya Dewan Kehormatan yang mempunyai tugas utama untuk melakukan pengawasan atas pelaksanaan kode etik tidak lain adalah sematamata untuk kepentingan para Notaris sendiri, yang mempunyai ikatan dengan pengawasan yang dilakukan Majelis Pengawas yang telah ditentukan oleh undang-undang.

Salah satu pembaharuan dalam pemberlakuan Pasal 66 UUJN adalah adanya kewenangan Majelis Kehormatan Notaris dalam proses peradilan terhadap Notaris. Isu hukum dalam penelitian ini adalah ketentuan Pasal 66 yang menuai kontroversi karena dinilai membatasi kewenangan dari penegakan hukum seperti hakim, Jaksa Penuntut Umum dan penyidik. Pasal 66 Ayat (1) pada frasa 'dengan persetujuan Majelis Kehormatan Notaris (MKN) dianggap bertentangan dengan Undang-Undang Dasar Negara Republik Indonesia 1945, sehingga Pasal 66 Ayat (3), (4) demi hukum juga harus dibatalkan. Ketentuan tersebut membatasi kewenangan dari Hakim, Jaksa Penuntut Umum, dan Penyidik untuk menegakkan hukum. Hal tersebut terkesan seolah-olah kewenangan hakim, Jaksa Penuntut Umum dan penyidik berada di bawah kewenangan MKN. Hal ini bertentangan dengan kewajiban seorang notaris sebagai warga negara yang memiliki kedudukan yang sama di hadapan hukum. Sebelumnya dalam pengujian Pasal 66 Ayat (1) UU No 30 Tahun 2004 yang diuji adalah frasa yang menyatakan bahwa dengan persetujuan Majelis Pengawas Daerah. Dalam Putusan MK No. 49/PUU-X/2012 terkait pengujian tersebut sudah menyatakan pemeriksaan proses hukum yang melibatkan notaris tak perlu persetujuan Majelis Pengawas Daerah (MPD).

Berdasarkan Pasal 66 UU Nomor 2 Tahun 2014, untuk kepentingan proses peradilan, penyidik, penuntut umum, atau hakim dengan persetujuan MKN berwenang: 1. mengambil fotokopi Minuta Akta dan/atau surat-surat yang dilekatkan pada Minuta Akta atau Protokol Notaris dalam penyimpanan Notaris; 2. memanggil Notaris untuk hadir dalam pemeriksaan yang berkaitan dengan Akta atau Protokol Notaris yang berada dalam penyimpanan Notaris.

Pasal 66A Perubahan UUJN menyatakan bahwa dalam melaksanakan pembinaan, Menteri membentuk Majelis Kehormatan Notaris. Masih dalam Pasal yang sama dinyatakan komposisi Majelis Kehormatan Notaris berjumlah tujuh orang, terdiri atas unsur: 1). Notaris sebanyak tiga orang, 2). Pemerintah sebanyak dua orang, 3). ahli atau akademisi sebanyak dua orang. 
Menurut Pasal 67, pengawasan Notaris dilakukan oleh menteri dan dalam melaksanakan pengawasan Notaris, Menteri membentuk Majelis Pengawas Notaris yang terdiri dari atas tiga orang dari pemerintah, tiga orang dari organisasi notaris, dan tiga orang dari akademisi yang kesemuanya berjumlah sembilan orang.

Setelah dibaca Pasal 66A dan 67 Perubahan UUJN tampak jelas perbedaan kedua majelis itu. Majelis Kehormatan Notaris (MKN) berwenang melakukan "pembinaan", Majelis Pengawas Notaris (MPN) berwenang melakukan "pengawasan". Kerancuan nampak setelah mencermati Pasal 1 UU Nomor 2 Tahun 2014, karena tidak ditemukan pengertian MKN, tetapi hanya ditemukan pengertian MPN. Dalam Pasal 1 angka 6 dikatakan bahwa MPN adalah suatu badan yang mempunyai kewenangan dan kewajiban untuk melaksanakan pembinaan dan pengawasan terhadap Notaris. Hal ini menunjukkan ada kekurang cermatan dalam mengubah UUJN dan berakibat pada ketidaksinkronan antara Pasal 1 angka 6, Pasal 66A dan Pasal 67. Dalam Pasal 66A dijelaskan bahwa kewenangan pembinaan itu ada pada MKN, bukan pada MPN, sedangkan menurut Pasal 1 angka 6 kewenangan pembinaan berada pada MPN. Apabila diasumsikan MKN merupakan bagian dari MPN, maka tidak ditemukan ketentuan yang mengatakan bahwa MKN merupakan bagian dari MPN. ${ }^{8}$

Dari uraian latar belakang di atas maka permasalahan yang ada yaitu, 1) Bagaimanakah kebijakan hukum pidana terhadap pembatasan kewenangan dalam penyidikan terhadap Notaris?; dan 2) Bagaimanakah implikasi hukum atas pembatasan kewenangan dalam penyidikan terhadap Notaris?

Penelitian ini menggunakan pendekatan yuridis normatif dan yuridis empiris. Pengumpulan data dilakukan dengan studi pustaka dan studi lapangan. Analisa data dilakukan secara kualitatif.

\section{B. Pembahasan}

\section{Kebijakan Hukum Pidana terhadap Pembatasan Kewenangan dalam Penyidikan Notaris}

Kebijakan formulasi hukum pidana pada dasarnya merupakan bagian dari proses penegakan hukum pidana, yaitu upaya yang ditempuh untuk menjamin kepastian hukum, ketertiban dan perlindungan hukum dengan menjaga keselarasan, keseimbangan dan keserasian antara moralitas sipil yang didasarkan oleh nilai-nilai aktual di dalam masyarakat beradab. Sebagai suatu proses kegiatan yang meliputi berbagai pihak termasuk

8 http://medianotaris.com/melawanputusanmk/berita384.html (diakses tanggal 19 Januari 2016). 
masyarakat dalam kerangka pencapaian tujuan, adalah merupakan keharusan untuk melihat penegakan hukum pidana sebagai suatu sistem peradilan pidana $^{9}$

Kebijakan hukum pidana yang dimaksud dalam penelitian ini adalah pada tahap formulasi, yaitu tahap penegakan hukum pidana in abstracto oleh badan pembuat undang-undang. Pembuat pembuat undang-undang dalam tahap ini melakukan kegiatan memilih nilai-nilai yang sesuai dengan keadaan dan situasi masa kini dan yang akan datang, kemudian merumuskannya dalam bentuk peraturan perundang-undangan pidana untuk mencapai hasil perundang-undangan yang paling baik dalam arti memenuhi syarat keadilan (kepastian dan kemanfaatan hukum) serta daya guna. Tahap ini disebut Tahap Kebijakan Legislatif. ${ }^{10}$

Tahap formulasi hukum pidana terhadap pembatasan kewenangan penyidik dalam penyidikan notaris terdapat dalam Pasal 66 Undang-Undang Nomor 2 Tahun 2014 tentang Jabatan Notaris sebagai berikut:

a. Untuk kepentingan proses peradilan, penyidik, penuntut umum, atau hakim dengan persetujuan majelis kehormatan Notaris berwenang:

1) mengambil fotokopi Minuta Akta dan/atau surat-surat yang dilekatkan pada Minuta Akta atau Protokol Notaris dalam penyimpanan Notaris; dan

2) memanggil Notaris untuk hadir dalam pemeriksaan yang berkaitan dengan Akta atau Protokol Notaris yang berada dalam penyimpanan Notaris.

b. Pengambilan fotokopi Minuta Akta atau surat-surat sebagaimana dimaksud pada Ayat (1) huruf a, dibuat berita acara penyerahan.

c. Majelis kehormatan Notaris dalam waktu paling lama 30 (tiga puluh) hari kerja terhitung sejak diterimanya surat permintaan persetujuan sebagaimana dimaksud pada Ayat (1) wajib memberikan jawaban menerima atau menolak permintaan persetujuan.

d. Dalam hal majelis kehormatan Notaris tidak memberikan jawaban dalam jangka waktu sebagaimana dimaksud pada Ayat (3), majelis kehormatan Notaris dianggap menerima permintaan persetujuan.

Sesuai dengan ketentuan di atas maka kewenangan Majelis Kehormatan Notaris dalam kepentingan proses peradilan adalah memberikan persetujuan kepada penyidik, penuntut umum, atau hakim untuk mengambil fotokopi Minuta Akta dan/atau surat-surat yang dilekatkan pada Minuta Akta atau Protokol Notaris dalam penyimpanan Notaris. Selain itu Majelis Kehormatan Notaris berwenang memanggil Notaris untuk hadir dalam

\footnotetext{
${ }^{9}$ Arief, Barda Nawawi. (2002). Bunga Rampai Kebijakan Hukum Pidana. Bandung: PT Citra Aditya Bakti, p. 12.

${ }^{10}$ Ibid., p. 12-13.
} 
pemeriksaan yang berkaitan dengan Akta atau Protokol Notaris yang berada dalam penyimpanan Notaris.

Pasal 66A Perubahan UUJN menyatakan bahwa dalam melaksanakan pembinaan, Menteri membentuk Majelis Kehormatan Notaris. Masih dalam pasal yang sama dinyatakan komposisi Majelis Kehormatan Notaris berjumlah tujuh orang, terdiri atas unsur: 1). Notaris sebanyak tiga orang, 2). Pemerintah sebanyak dua orang, 3). ahli atau akademisi sebanyak dua orang.

Berdasarkan penjelasan M. Reza Berawi ${ }^{11}$ semenjak disahkannya Undang-Undang Nomor 2 Tahun 2014 Tentang Perubahan Atas UndangUndang Nomor 30 Tahun 2004 Tentang Jabatan Notaris pada awal Tahun 2014 yang lalu, telah hadir lembaga baru bernama Majelis Kehormatan Notaris, didasari oleh Pasal 66 dan Pasal 66A UU Perubahan Nomor 2 Tahun 2014 tentang Jabatan Notaris. Peran penting lembaga baru ini adalah menggantikan peran yang telah dilakukan oleh Majelis Pengawas Daerah dalam memberikan persetujuan tindakan kepolisian terhadap Notaris.

Peran dan kewenangan Majelis Pengawas Daerah sebelumnya terdapat dalam Pasal 66 Undang-Undang Nomor 30 Tahun 2004 Tentang Jabatan Notaris yang nyaris sama dengan peran Majelis Kehormatan Notaris itu telah dihapuskan oleh Mahkamah Konstitusi Republik Indonesia dengan Putusan Mahkamah Konstitusi Republik Indonesia Nomor 49/PUU-X/2013 karena bertentangan dengan konstitusi negara Indonesia. Selanjutnya yang kemudian yang menjadi persoalan adalah apakah kewenangan Majelis Kehormatan Notaris telah sesuai dengan putusan Mahkamah Konstitusi Republik Indonesia Nomor 49/PUU-X/2012.

Lebih lanjut menurut Pasal 67 Undang-Undang Nomor 2 Tahun 2014, pengawasan Notaris dilakukan oleh menteri dan dalam melaksanakan pengawasan Notaris, Menteri membentuk Majelis Pengawas Notaris yang terdiri dari atas tiga orang dari pemerintah, tiga orang dari organisasi notaris, dan tiga orang dari akademisi yang kesemuanya berjumlah sembilan orang.

a. Pengawasan atas Notaris dilakukan oleh Menteri.

b. Dalam melaksanakan pengawasan sebagaimana dimaksud pada Ayat (1) Menteri membentuk Majelis Pengawas.

c. Majelis Pengawas sebagaimana dimaksud pada Ayat (2) berjumlah 9 (sembilan) orang, terdiri atas unsur:

1) Pemerintah sebanyak 3 (tiga) orang;

2) Organisasi Notaris sebanyak 3 (tiga) orang; dan

3) ahli atau akademisi sebanyak 3 (tiga) orang.

d. Dalam hal suatu daerah tidak terdapat unsur instansi pemerintah sebagaimana dimaksud pada Ayat (3) huruf a, keanggotaan dalam Majelis Pengawas diisi dari unsur lain yang ditunjuk oleh Menteri.

\footnotetext{
${ }^{11}$ Hasil wawancara dengan M. Reza Berawi selaku Notaris. Selasa 19 Januari 2016.
} 
e. Pengawasan sebagaimana dimaksud pada Ayat (1) meliputi perilaku (integritas) Notaris dan pelaksanaan jabatan Notaris.

f. Ketentuan mengenai pengawasan sebagaimana dimaksud pada Ayat (5) berlaku bagi Notaris Pengganti dan Pejabat Sementara Notaris.

Sesuai dengan ketentuan Pasal 66A dan Pasal 67 Undang-Undang Nomor 2 Tahun 2014 maka akan tampak jelas perbedaan kewenangan kedua majelis, yaitu apabila Majelis Kehormatan Notaris berwenang melakukan pembinaan, sedangkan Majelis Pengawas Notaris berwenang melakukan pengawasan.

Pasal 1 Undang-undang Nomor 2 Tahun 2014 tidak ditemukan pengertian Majelis Kehormatan Notaris, tetapi hanya dijelaskan pengertian Majelis Pengawas Notaris. Pasal 1 angka 6 dikatakan bahwa Majelis Pengawas Notaris adalah suatu badan yang mempunyai kewenangan dan kewajiban untuk melaksanakan pembinaan dan pengawasan terhadap Notaris. Hal yang menjadi pertimbangan hukum Mahkamah Konstitusi menghapuskan kewenangan Majelis Pengawas Daerah sebagaimana termuat dalam putusan, yang menyatakan:

a. Frasa "dengan persetujuan Majelis Pengawas Daerah" dalam Pasal 66 Ayat (1) Undang-Undang Nomor 30 Tahun 2004 tentang Jabatan Notaris bertentangan dengan Undang-Undang Dasar Negara Republik Indonesia Tahun 1945

b. Frasa "dengan persetujuan Majelis Pengawas Daerah" dalam Pasal 66 Ayat (1) Undang-Undang Nomor 30 Tahun 2004 tentang Jabatan Notaris tidak mempunyai kekuatan hukum mengikat. ${ }^{12}$

Sesuai dengan uraian di atas maka diketahui frasa "dengan persetujuan Majelis Pengawas Daerah" yang terdapat dalam Pasal 66 Undang-Undang Nomor 30 Tahun 2004 tentang jabatan notaris telah dinyatakan bertentangan dengan Pasal Undang-Undang Dasar Tahun 1945 (UUD 1945), tepatnya bertentangan dengan Pasal 27 Ayat (1) dan Pasal 28D Ayat (1) UUD 1945.

Terkait dengan perlindungan hukum terhadap Notaris, di mana Notaris sebagai Pejabat Umum memiliki kewenangan untuk membuat akta otentik seperti maksud Undang-Undang Nomor 2 Tahun 2014 tentang perubahan atas Undang-Undang Nomor 30 Tahun 2004 tentang Jabatan Notaris. Akta bisa disebut otentik pada dasarnya harus memuat kebenaran formal sesuai dengan apa yang diberitahukan para pihak kepada notaris. Oleh sebab itu, memang adanya perlindungan hukum terhadap notaris dibutuhkan dalam menjalankan jabatannya selaku pejabat umum.

12 Anshori, Abdul Ghofur. (2009). Lembaga Kenotariatan Indonesia Perspektif Hukum dan Etika. Yogyakarta: UII Press, p. 37. 
Menurut penjelasan Rugun $\mathrm{HS}^{13}$ notaris mempunyai kewajiban untuk memasukkan bahwa apa yang termuat dalam Akta Notaris sungguh-sungguh telah dimengerti dan sesuai dengan kehendak para pihak, yaitu dengan cara membacakannya, sehingga menjadi jelas isi Akta Notaris, serta memberikan akses terhadap informasi, termasuk akses terhadap peraturan perundangundangan yang terkait bagi para pihak penandatangan akta.

Penjelasan di atas menunjukkan bahwa para pihak dapat menentukan dengan bebas untuk menyetujui atau tidak menyetujui isi Akta Notaris yang akan ditandatanganinya. Namun demikian, Akta otentik yang dibuat oleh Notaris tak jarang dipermasalahkan oleh salah satu pihak atau oleh pihak lain karena dianggap merugikan kepentingannya, baik itu dengan pengingkaran akan isi, tanda-tangan maupun kehadiran pihak di hadapan Notaris, bahkan adanya dugaan dalam Akta Otentik tersebut ditemukan keterangan palsu. Hal ini dimungkinkan dengan begitu banyaknya jenis Akta otentik yang dapat dibuat oleh Notaris.

Pada dasarnya perlindungan hukum terhadap Jabatan Notaris telah diatur secara teknis dalam Peraturan Menteri Hukum dan Hak Asasi Manusia Nomor: M.03.HT.03.10 Tahun 2007. Pada BAB III Permenkumham tersebut diatur tentang Syarat Dan Tata Cara Pengambilan Minuta Akta dan/atau Surat-Surat Yang Diletakan Pada Minuta Akta Atau Protokol Notaris Dalam Penyimpanan Notaris, yaitu dengan tata cara yaitu perlindungan Hukum yang diberikan terhadap (Jabatan) Notaris, baik yang diatur dalam Undang-Undang Jabatan Notaris maupun dalam ketentuanketentuan peraturan lainnya. Menurut penulis Undang-Undang Jabatan Notaris sudah cukup untuk memberikan perlindungan hukum bagi Notaris dalam menjalankan jabatannya guna menjaga kerahasiaan jabatannya. Perlindungan Hukum yang demikian, apabila tetap diikuti dengan "Hak stimewa", tidak menutup kemungkinan disalahgunakan atau dimanfaatkan oleh orang-orang yang tidak bertanggung jawab, baik itu melibatkan Notaris-nya ataupun tidak.

Menurut M. Reza Berawi ${ }^{14}$ persamaan kedududukan di depan hukum terkait perlunya pemanggilan dan kehadiran notaris dalam pemeriksaan perkara pidana, baik sebagai Ahli, Saksi maupun Tersangka/Terdakwa, dengan alasan sebagai berikut:

a. Sebagai Ahli, dalam hal ini notaris dipanggil dan perlu kehadirannya dalam pemeriksaan perkara pidana sebagai ahli hukum yang berwenang membuat akta autentik sehingga diperlukan pertimbangan hukum yang khusus sesuai keahliannya berkaitan dengan kewenangan dan tanggungjawab notaris serta hal yang dapat memberikan penjelasan

\footnotetext{
${ }^{13}$ Hasil wawancara dengan Rugun HS selaku Anggota Majelis Pengawas Notaris. Senin 18 Januari 2016.

${ }^{14}$ Hasil wawancara dengan M. Reza Berawi selaku Notaris. Selasa 19 Januari 2016.
} 
kepada Penyidik, Penuntut Umum, Hakim, maupun pihak pencari keadilan

b. Sebagai Saksi, dalam hal ini notaris dipanggil dan perlu kehadirannya dalam pemeriksaan perkara pidana, dalam kapasitas sebagai pejabat umum yang membuat akta autentik, diperlukan kesaksiannya terhadap apa yang dilihat, didengar dan bukti-bukti pendukung dalam pembuatan akta autentik tersebut, apakah dalam prosesnya terindikasi adanya perbuatan pidana atau tidak;

c. Sebagai Tersangka, dalam hal ini notaris dipanggil dan perlu kehadirannya dalam pemeriksaan perkara pidana sebagai tersangka berdasarkan bukti awal sehingga patut diduga adanya tindak pidana yang dilakukan notaris sebagai pembuat akta autentik, baik dilakukan sendiri maupun bersama-sama, yang ditemukan oleh penyidik, sehingga notaris harus mempertanggungjawabkan perbuatan tersebut di muka hukum;

Sesuai dengan penjelasan di atas maka "persamaan kedudukan dalam hukum" dan "perlindungan dan kepastian hukum yang adil" adalah merupakan hak konstitusional setiap warga negara Indonesia sekaligus pengakuan terhadap Hak Asasi Manusia yang tidak dapat dikurangi dalam keadaan atau situasi apapun;

Selanjutnya mengenai bentuk perlindungan hukum terhadap notaris melalui Majelis Pengawas Daerah yang dalam hal ini telah dibatalkan oleh putusan Mahkamah Konstitusi Nomor 49/PUU-X/2013 menurut penulis adalah sudah tepat, karena Profesi jabatan Notaris sebagaimana dimaksud dalam Pasal 66 Ayat (1) UU Jabatan Notaris, dibenarkan mendapat perlakuan yang berbeda sepanjang perlakuan itu berkaitan dengan tindakan dalam lingkup kode etik yaitu yang berkaitan dengan sikap, tingkah laku, dan perbuatan notaris dalam melaksanakan tugas yang berhubungan dengan moralitas. yang telah diatur dan diberikan perlindungan dalam Kode Etik Notaris.

Hubungan profesi notaris dengan organisasi profesi notaris diatur melalui kode etik notaris yang ditetapkan dan ditegakkan oleh organisasi notaris. Keberadaan kode etik notaris merupakan konsekuensi logis dari dan untuk suatu pekerjaan yang disebut sebagai profesi. Bahkan ada pendapat yang menyatakan bahwa notaris sebagai pejabat umum yang diberikan kepercayaan harus berpegang teguh tidak hanya pada peraturan perundangundangan, namun juga kode etik profesi, karena tanpa kode etik, harkat dan martabat dari profesinya akan hilang. ${ }^{15}$

Menurut penjelasan M. Fakih, diketahui bahwa pada dasarnya penegakan hukum terhadap notaris yang diduga melakukan tindak pidana

${ }^{15}$ Hasil wawancara dengan Helmi selaku Anggota Majelis Kehormatan Notaris. Selasa 19 Januari 2016. 
merupakan ranah aparat penegak hukum, tetapi apabila perbuatan notaris merupakan pelanggaran kode etik maka menjadi ranah MKN untuk melaksanakan sidang Kode Etik tersebut. Selanjutnya jika sudah ada putusan Mahkamah Konstitusi (MK) terhadap peraturan perundang-undangan maka yang menjadi acuan adalah Putusan MK. ${ }^{16}$

Adanya hubungan antara kode etik dan Undang-Undang Jabatan Notaris memberikan arti terhadap profesi notaris itu sendiri. Undang-Undang Jabatan Notaris dan kode etik notaris menghendaki agar notaris dalam menjalankan tugas jabatannya sebagai pejabat umum, selain harus tunduk pada Undang-Undang Jabatan Notaris juga harus taat pada kode etik profesi serta harus bertanggung jawab kepada masyarakat yang dilayaninya, organisasi profesi (Ikatan Notaris Indonesia atau INI) maupun terhadap negara. Dengan adanya hubungan ini, maka terhadap notaris yang mengabaikan keluruhan dari martabat jabatannya selain dapat dikenai sanksi moril, ditegur atau dipecat dari keanggotaan profesinya juga dapat dipecat dari jabatannya sebagai notaris. bahwa notaris dalam menjalankan tugas jabatannya:

a. Notaris dituntut melakukan pembuatan akta dengan baik dan benar. Artinya akta yang dibuat itu memenuhi kehendak hukum dan permintaan pihak-pihak yang berkepentingan karena jabatannya.

b. Notaris dituntut menghasilkan akta yang bermutu. Artinya, akta yang dibuatnya itu sesuai dengan aturan hukum dan kehendak pihak-pihak yang berkepentingan dalam arti yang sebenarnya, bukan mengada-ada. Notaris harus menjelaskan kepada pihak-pihak yang berkepentingan akan kebenaran isi dan produk akta yang dibuatnya itu.

c. Berdampak positif, artinya siapapun akan mengakui akta notaris itu mempunyai kekuatan bukti sempurna. ${ }^{17}$

Menurut M. Reza Berawi ${ }^{18}$ terkait dengan sanksi sebagai bentuk upaya penegakan kode etik notaris atas pelanggaran kode etik didefinisikan sebagai suatu hukuman yang dimaksudkan sebagai sarana, upaya dan alat pemaksa ketaatan dan didiplin notaris. Sanksi dalam kode etik notaris dituangkan dalam Pasal 6 yang menyatakan bahwa sanksi yang dikenakan terhadap anggota yang melakukan pelanggaran kode etik dapat berupa teguran, peringatan, skorsing (pemecatan sementara) dari keanggotaan perkumpulan, onzetting (pemecatan) dari keanggotaan perkumpulan dan pemberhentian dari keanggotaan perkumpulan. Dengan demikian tidak perlu lagi harus ada persetujuan Majelis Pengawas Daerah untuk memberikan

\footnotetext{
${ }^{16}$ Hasil wawancara dengan M. Fakih selaku Akademisi. Senin 28 Maret 2016.

17 Dewi, Santi dan Diradja, R.M Fauwas. (2011). Panduan Teori dan Praktik Notaris. Yogyakarta: Pustaka Yustisia, p. 65-66.

${ }^{18}$ Hasil wawancara dengan M. Reza Berawi selaku Notaris. Selasa 19 Januari 2016.
} 
persetujuan tindakan kepolisian terhadap Notaris dikarenakan dalam organisasi notaris telah ada penegakan kode etik jabatan.

Menurut analisis penulis terkait dengan notaris yang terlibat dalam proses peradilan karena melakukan tindak pidana maka kewenangan Majelis Kehormatan Notaris Berdasarkan Undang-Undang Nomor 2 Tahun 2014 tentang Jabatan Notaris dapat dianggap sebagai suatu kewenangan yang kontraproduktif dengan proses penegakan hukum itu sendiri, karena Majelis Kehormatan Notaris seperti membatasi kewenangan hakim, jaksa dan penyidik dalam melaksanakan tugas dan fungsinya sebagai aparat penegak hukum dalam melaksanakan proses peradilan bagi notaris yang melakukan suatu tindak pidana tertentu.

Sesuai dengan teori kewenangan, bahwa secara organisasi kewenangan adalah kemampuan yuridis yang didasarkan pada hukum publik, terdapat kewenangan diikatkan pula hak dan kewajiban, yaitu agar kewenangan tidak semata-mata diartikan sebagai hak berdasarkan hukum publik, tetapi juga kewajiban sebagai hukum publik. Kewenangan tidak hanya diartikan sebagai kekuasaan, oleh karena itu, dalam menjalankan hak berdasarkan hukum publik selalu terikat kewajiban berdasarkan hukum publik tidak tertulis atau asas umum pemerintahan yang baik. ${ }^{19}$

Sesuai dengan teori tersebut maka kewenangan kewenangan Majelis Kehormatan Notaris terhadap proses peradilan bagi notaris merupakan kewenangan tersebut bersifat organisasional yang didasarkan pada hukum publik yaitu Undang-Undang Nomor 2 Tahun 2014 tentang Jabatan Notaris. Melalui aturan hukum ini maka Majelis Kehormatan Notaris memiliki hak dan kewajiban, terkait dengan notaris yang menjalani proses peradilan, sebagaimana diatur dalam Pasal 66 Ayat (1) Undang-Undang Nomor 2 Tahun 2014 bahwa untuk kepentingan proses peradilan, penyidik, penuntut umum, atau hakim dengan persetujuan majelis kehormatan Notaris berwenang mengambil fotokopi Minuta Akta dan/atau surat-surat yang dilekatkan pada Minuta Akta atau Protokol Notaris dalam penyimpanan Notaris; danmemanggil Notaris untuk hadir dalam pemeriksaan yang berkaitan dengan Akta atau Protokol Notaris yang berada dalam penyimpanan Notaris.

Kewenangan adalah fungsi untuk menjalankan kegiatan dalam organisasi, sebagai hak untuk memerintah orang lain untuk melakukan atau tidak melakukan sesuatu agar tujuan dapat tercapai. Pengorganisasian merupakan proses penyusunan struktur organisasi yang sesuai dengan tujuan organisasi, sumber daya-sumber daya yang dimilikinya dan lingkungan yang melingkupinya.

${ }^{19}$ Admosudirjo, Prajudi. Op. Cit., p. 6. 
Sesuai dengan pengertian di atas maka kewenangan adalah fungsi Majelis Kehormatan Notaris untuk menjalankan kegiatan sebagaimana diatur dalam Pasal 66 Ayat (2) Undang-Undang Nomor 2 Tahun 2014, yaitu pengambilan fotokopi Minuta Akta atau surat-surat sebagaimana dimaksud pada Ayat (1) huruf a, dibuat berita acara penyerahan. Pasal 66 Ayat (3) menjelaskan bahwa Majelis kehormatan Notaris dalam waktu paling lama 30 (tiga puluh) hari kerja terhitung sejak diterimanya surat permintaan persetujuan sebagaimana dimaksud pada Ayat (1) wajib memberikan jawaban menerima atau menolak permintaan persetujuan.

Berdasarkan uraian di atas dapat dinyatakan bahwa Pembentukan Majelis Kehormatan Notaris sebagai pengganti Majelis Pengawas Daerah sebagaimana diatur dalam Undang-Undang Nomor 2 tahun 2014, semakin menjauhkan makna pengawasan yang sebenarnya terhadap notaris, apalagi bila dilihat saat ini belum ada payung hukum mengenai peraturan pelaksanaan dari pembentukan Majelis Kehormatan Notaris tersebut. Oleh karena itu dituntut kehati-hatian yang tinggi bagi praktisi notaris dalam melaksanakan tugas dan kewenangannya dalam pembuatan akta otentik.

Majelis Kehormatan Notaris (MKN) dan Peraturan Menterinya sampai saat ini belum terbentuk sebagaimana diamanatkan dalam Pasal 66 dan Pasal 66 A UUJN, demikian pula peraturan pelaksanaannya sebagaimana diamanatkan dalam pasal 91B Undang-Undang Nomor 2 Tahun 2014 tentang Jabatan Notaris, juga belum dibuat, maka penyidikan terhadap Notaris saat ini masih berlaku seperti pada peraturan sebelumnya, yaitu Undang-Undang Nomor 30 Tahun 2004 tentang Jabatan Notaris.

Berdasarkan hasil penelitian di atas maka terkait dengan kebijakan hukum pidana terhadap pembatasan kewenangan dalam penyidikan terhadap Notaris, maka pandangan penulis adalah terdapat perbedaan dalam pelaksanaan penyidikan tindak pidana yang berkaitan dengan profesi Notaris, terutama dalam hal pemanggilan dan pemeriksaannya. Perbedaannya adalah pada tata cara atau mekanisme pemanggilannya, yaitu penyidik harus minta persetujuan Majelis Kehormatan Notaris (MKN) untuk memeriksa Notaris yang diduga melakukan tindak pidana. Ada tenggang waktu 1 (satu) bulan untuk memperoleh jawaban persetujuan dari Majelis Kehormatan Notaris (MKN). Saat ini untuk memanggil Notaris, maka penyidik harus merujuk pada Pasal 66 Undang-Undang Nomor 2 Tahun 2014, tentang perubahan atas Undang-Undang Nomor 30 Tahun 2004 tentang Jabatan Notaris.

Tempo 30 hari yang diberikan Undang-Undang kepada Majelis Kehormatan Notaris (MKN) tersebut adalah waktu yang final, artinya dalam waktu 30 hari tersebut MKN harus secara cepat memeriksa dan mengklarifikasi Notaris dimaksud guna menentukan "disetujui" atau "tidak disetujui" permintaan pemeriksaan oleh penyidik atas Notaris dimaksud. 
Apabila disetujui apa kriterianya dan kalau tidak disetujui apa alasannya, ini yang harus terukur dan dapat diterima secara akal sehat serta sesuai fakta hukum yang ada. Hal ini tentunya tidak selaras dengan salah satu azas hukum dalam Hukum Acara Pidana, yaitu adanya persamaan hak dimuka hukum terhadap setiap orang, sebelum yang bersangkutan diputus bersalah oleh Hakim.

Hal ini pada sisi lain juga dapat merugikan hak para Notaris dan semakin membebani tugas para Notaris dalam menjalankan tugas dan jabatannya dalam pembuatan akta-akta autentik. Dengan adanya putusan Mahkamah Konstitusi tersebut, maka banyak timbul kegelisahan dari para praktisi Notaris, karena hak istimewa untuk diperlakukan dan dilindungi dalam melaksanakan tugas dan jabatannya atas nama negara sebagai Notaris menjadi hilang. Notaris dalam menjalankan tugasnya selalu memperhatikan syarat-syatat atau ketentuan-ketentuan yang ditetapkan oleh Undang-undang demi terjaminnya kepastian hukum bagi pihak-pihak yang membuat perjanjian.

Kewenangan Majelis Kehormatan Notaris dalam hal ini merupakan kemampuan untuk melakukan tindakan hukum publik, atau secara yuridis kewenangan adalah kemampuan bertindak yang diberikan undang-undang untuk melakukan hubungan-hubungan hukum, khususnya proses peradilan terhadap notaris. Pengecualian dilakukan terhadap notaris yang tertangkap tangan melakukan tindak pidana, maka tidak diperlukan adanya rekomendasi dari MKN, sehingga aparat penegak hukum (penyidik) dapat secara langsung melakukan proses hukum terhadap notaris yang tertangkap tangan melakukan tindak pidana tersebut.

Keistimewaan dalam proses peradilan dalam prinsip kesetaraan harusnya diberikan kepada subjek yang tepat dalam hal subjek hukum adalah kelompok masyarakat tertentu atau kelompok warga masyarakat tertentu, anak atau kelompok rentan, ataupun dalam hal perlindungan saksi dan korban. Dalam hal ini diperlukan adanya perlakuan yang menjaga harkat dan martabat pejabat negara dan lembaga negara agar tidak diperlakukan secara sewenang-wenang, namun perlakuan demikian tidak boleh bertentangan dengan prinsip-prinsip legalitas atau kepastian hukum dalam peradilan pidana, apalagi sampai berakibat pada terhambatnya proses hukum.Hukum berasal dari masyarakat dan hidup serta berproses di dalam masyarakat, maka pembaharuan hukum tidak mungkin dilepaskan secara mutlak dari masyarakat. Sistem pemidanaan adalah keseluruhan peraturan yang mengatur bagaimana hukum pidana ditegakkan secara nyata sehingga orang dijatuhi sanksi berupa pidana. ${ }^{20}$

${ }^{20}$ Rosidah, Nikmah. (2014), Budaya Hukum Hakim Anak di Indonesia. Sebuah Pendekatan Hukum Progresif. Semarang: Pustaka Magister, p. xii. 
Keharusan persetujuan Majelis Pengawas Daerah bertentangan dengan prinsip independensi dalam proses peradilan dan bertentangan dengan kewajiban seorang Notaris sebagai warga negara yang memiliki kedudukan sama di hadapan hukum serta bertentangan dengan prinsip kesamaan di depan hukum, karena kewenangan yang dimiliki Majelis Kehormatan Notaris dalam menyetujui pemanggilan Notaris dan pengambilan fotokopi protokol Notaris oleh penyidik, penuntut umum dan hakim adalah sama dengan kewenangan yang dimiliki oleh Majelis Pengawas Daerah yang telah dibatalkan Mahkamah Konstitusi.

Hal ini bermakna bahwa saat saat ini penyidik dalam melakukan penyidikan terhadap Notaris (mengingat MKN dan Peraturan pelaksanaannya belum terbentuk sesuai amanat Undang-Undang Nomor 2 Tahun 2014 dan Undang-Undang Jabatan Notaris Tahun 2004), sehingga tidak ada lagi mekanisme izin dari Majelis Pengawas Daerah (MPD) sebagaimana diputuskan oleh Mahkamah Konstitusi, sehingga penyidik dapat langsung memanggil Notaris untuk diperiksa demikian pula penyidik dapat langsung melakukan penyitaan terhadap fotokopi minuta akta dan/atau surat-surat yang dilekatkan pada minuta akta Notaris.

\section{Implikasi Hukum terhadap Pembatasan Kewenangan dalam Penyidikan terhadap Notaris}

Implikasi hukum adalah dampak yang terjadi dalam praktik atau pelaksanaan aturan hukum setelah diberlakukan suatu produk hukum atau peraturan perundang-undangan. ${ }^{21}$ Sesuai dengan pengertian ini maka yang dimaksud dengan implikasi hukum dalam penelitian ini adalah dampak setelah diberlakukannya ketentuan Pasal 66 dan Pasal 66 A Undang-Undang Nomor 2 Tahun 2014 tentang Jabatan Notaris terhadap praktik penyidikan notaris yang diduga melakukan tindak pidana.

Implikasi hukum atas pembatasan kewenangan dalam penyidikan terhadap Notaris berdampak pada proses peradilan bagi notaris yang berwenang memberikan persetujuan kepada penyidik, penuntut umum, atau hakim untuk mengambil fotokopi Minuta Akta dan/atau surat-surat yang dilekatkan pada Minuta Akta atau Protokol Notaris dalam penyimpanan Notaris dalam kepentingan proses peradilan adalah dapat dinyatakan bertentangan dengan asas kesamaan warganegara di depan hukum sebagaimana diatur dalam UUD 1945.

Menurut penjelasan M. Fakih, Penegakan hukum terhadap notaris yang melakukan tindak pidana semestinya relevan dengan kedudukan yang sama di hadapan hukum. Seorang notaris sebagai warga negara yang

21 http://dilihatya.com/2411/pengertian-implikasi-menurut-para-ahli. (diakses 17 Februari 2016). 
memiliki kedudukan yang sama di hadapan hukum sebagaimana diatur dalam Pasal 27 Ayat (1), Pasal 28D Ayat (1) UUD 1945. Apabila notaris terbukti melakukan tindak pidana maka implikasi hukum terhadap klien maupun calon klien adalah hilangnya kepecercayaan masyarakat terhadap notaries yang bersangkutan. ${ }^{22}$

Sebelumnya Pengujian Pasal 66 Ayat (1) UU 30/2004 terkait frasa yang menyatakan "dengan persetujuan Majelis Pengawas Daerah". Putusan MK No. 49/PUU-X/2012 terkait pengujian tersebut dinyatakan pemeriksaan proses hukum yang melibatkan notaris tak perlu persetujuan Majelis Pengawas Daerah (MPD).

Notaris yang melakukan suatu tindak pidana seharusnya dilaksanakan proses peradilan dan penegakan hukum sesuai dengan sistem hukum yang berlaku, yaitu melalui pemidanaan. Menurut Nikmah Rosidah, pemidanaan merupakan penjatuhan pidana/sentencing sebagai upaya yang sah yang dilandasi oleh hukum untuk mengenakan nestapa penderitaan pada seseorang yang melalui proses peradilan pidana terbukti secara sah dan meyakinkan bersalah melakukan suatu tindak pidana. ${ }^{23}$

Majelis Kehormatan Notaris seharusnya tidak diberikan kewenangan untuk menyetujui atau tidak menyetujui proses peradilan yang sedang berjalan. Keberadaan MKN dapat dilihat dalam ketentuan pasal 66 Ayat (1) Undang-undang Nomor 2 Tahun 2014 tentang perubahan atas UndangUndang Nomor 30 Tahun 2004 tentang Jabatan Notaris, adalah: Untuk kepentingan proses peradilan, penyidik, penuntut umum, atau hakim dengan persetujuan majelis kehormatan Notaris berwenang mengambil fotokopi Minuta Akta dan/atau surat-surat yang dilekatkan pada Minuta Akta atau Protokol Notaris dalam penyimpanan Notaris; dan memanggil Notaris untuk hadir dalam pemeriksaan yang berkaitan dengan Akta atau Protokol Notaris yang berada dalam penyimpanan Notaris.

Kewenangan yang dimiliki oleh majelis kehormatan notaris yang terdapat dalam Undang-Undang Nomor 2 Tahun 2014 tentang Perubahan atas Undang-Undang Nomor 30 Tahun 2004 tentang Jabatan Notaris terdapat sikap berlawanan dengan apa yang telah diputuskan oleh mahkamah konstitusi dalam putusannya nomor 49/PUU-X/2012 yang mana telah menghapuskan kewenangan majelis pengawas daerah dalam hal memberikan persetujuan tindakan kepolisian terhadap notaris. Berdasarkan hal tersebut maka kewenangan yang dimiliki oleh Majelis Kehormatan Notaris adalah merupakan kewenangan prosedural, karena kewenangan Majelis

\footnotetext{
${ }^{22}$ Hasil wawancara dengan Fakih selaku Akademisi Fakultas Hukum Unila. Senin, 28 Maret 2016.

${ }^{23}$ Rosidah, Nikmah. (2011). Asas-Asas Hukum Pidana. Semarang: Penerbit Pustaka Magister, p.68.
} 
Kehormatan Notaris tersebut berasal dari peraturan perundang-undangan, terutama Undang-Undang Jabatan Notaris. Sedangkan dalam hal pelaksanaan berbagai wewenangnya, MKN harus memperhatikan berbagai syarat pelaksanaan yang dinyatakan dalam peraturan perundangan.

Berdasarkan Undang-Undang Nomor 30 Tahun 2004 tentang Jabatan Notaris, kewenangan pemberian persetujuan pemeriksaan Notaris untuk kepentingan proses peradilan, pada mulanya berada pada Majelis Pengawas Daerah. Dengan adanya putusan Mahkamah Konstitusi Nomor 49/PUU$\mathrm{X} / 2012$ tertanggal 28 Mei 2012, yang menghapus frasa "dengan persetujuan Majelis Pengawas Daerah" pada Pasal 66 Ayat (1) Undang-Undang Nomor 30 Tahun 2004 tentang Jabatan Notaris, kewenangan tersebut dihapus. Setelah diundangkannya Undang-Undang Nomor 2 Tahun 2014 tentang Perubahan Atas Undang-Undang Nomor 30 Tahun 2004 tentang Jabatan Notaris, kewenangan pemberian persetujuan pemeriksaan Notaris untuk kepentingan proses peradilan muncul kembali dan dibebankan kepada Majelis Kehormatan Notaris. Tentang apa yang menjadi kewenangan lembaga baru yang bernama Majelis Kehormatan Notaris dapat kita lihat dalam ketentuan Pasal 66 Ayat (1) Undang-Undang Nomor 2 Tahun 2014 tentang perubahan atas Undang-Undang Nomor 30 Tahun 2004 tentang Jabatan Notaris yang menyatakan, bahwa untuk kepentingan proses peradilan, penyidik, penuntut umum, atau hakim dengan persetujuan majelis kehormatan Notaris berwenang mengambil fotokopi Minuta Akta dan/atau surat-surat yang dilekatkan pada Minuta Akta atau Protokol Notaris dalam penyimpanan Notaris; dan memanggil Notaris untuk hadir dalam pemeriksaan yang berkaitan dengan Akta.

Selain hal tersebut yang terdapat diatas dalam Pasal yang lain juga disebutkan mengenai kewenangan ini bahwa dalam melaksanakan pembinaan. enteri membentuk majelis kehormatan Notaris Majelis Kehormatan Notaris berjumlah 7 (tujuh) orang, terdiri atas unsur: Notaris sebanyak 3 (tiga) orang, Pemerintah sebanyak 2 (dua) orang, dan ahli atau akademisi sebanyak 2 (dua) orang. Ketentuan lebih lanjut mengenai tugas dan fungsi, syarat dan tata cara pengangkatan dan pemberhentian, struktur organisasi, tata kerja, dan anggaran majelis kehormatan Notaris diatur dengan Peraturan Menteri.

Setelah menelaah Pasal 66 dan Pasal 66A Undang-undang Nomor 2 Tahun 2014 tentang Perubahan atas Undang-Undang Nomor 30 Tahun 2004 tentang Jabatan Notaris maka tampak jelas bahwa tugas dan fungsi, syarat dan tata cara pengangkatan dan pemberhentian, struktur organisasi, tata kerja, dan anggaran Majelis Kehormatan Notaris diatur dengan Peraturan Menteri. Putusan mahkamah konstitusi Nomor 49/PUU-X/2012 para hakim mahkamah telah mempertimbangkan tentang proses tindakan kepolisian oleh penyidik, untuk mengambil dokumen-dokumen dalam penyimpanan notaris 
dan memanggil notaris untuk hadir dalam pemeriksaan yang berkaitan dengan dokumen-dokumen yang dibuatnya yang hanya dapat dilakukan dengan persetujuan Majelis Pengawas Daerah, menurut Mahkamah termasuk dalam kelompok pengaturan yang seharusnya tidak mengandung perlakuan berbeda yang bertentangan dengan prinsip equal protection sebagaimana yang dijamin oleh Pasal 27 Ayat (1) dan Pasal 28D Ayat (3) UUD 1945 yaitu persamaan atau kesederajatan di hadapan hukum dan pemerintahan;

Dengan demikian Mahkamah Konstitusi adalah salah satu pelaku kekuasaan kehakiman disamping Mahkamah Agung. Namun Mahkamah Konstitusi didesain khusus sebagai salah satu pelaku kekuasaan kehakiman yang bersifat tunggal. Tidak memiliki peradilan di bawahnya dan tidak pula merupakan bawahan dari lembaga lain. Hal inilah yang membedakan putusan Mahkamah Konstitusi dengan putusan peradilan lainnya. Hal tersebut tidak terlepas dari kewenangan yang menjadi kompetensi Mahkamah Konstitusi sebagai sebuah pengadilan konstitusional yang difokuskan kepada sengketa ketatanegaraan dan berdasarkan konstitusi. Sifat putusan Mahkamah Konstitusi pun berbeda dengan peradilan konvensional lainnya yang memberi akses bagi para pihak untuk melakukan upaya hukum lebih lanjut. ${ }^{24}$

Secara umum putusan MK berisi pernyataan apa yang menjadi hukumnya dan sekaligus dapat meniadakan keadaan hukum dan menciptakan keadaan hukum baru. Dalam perkara pengujian UU, putusan yang mengabulkan bersifat menyatakan apa yang menjadi hukum dari suatu norma undang-undang, yaitu bertentangan dengan UUD 1945. Pada saat yang bersamaan, putusan tersebut meniadakan keadaan hukum berdasarkan norma yang dibatalkan dan menciptakan keadaan hukum baru.

Seluruh proses penegakan hukum terhadap notaris sebagaimana telah dirumuskan di atas harus dilakukan tanpa campur tangan atau intervensi dari kekuasaan lain di luar peradilan, dalam hal ini termasuk juga dengan kewenangan Majelis Kehormatan Notaris untuk memberikan persetujuan tindakan kepolisian terhadap notaris. Hal demikian sejalan dengan prinsip penyelenggaraan kekuasaan peradilan yang merdeka sebagaimana diatur dalam Pasal 24 UUD 1945 dan Pasal 3 Ayat (2) Undang-Undang Nomor 48 Tahun 2009 tentang Kekuasaan Kehakiman yang menegaskan,"Segala campur tangan dalam urusan peradilan oleh pihak lain di luar kekuasaan kehakiman dilarang, kecuali dalam hal-hal sebagaimana dimaksud dalam Undang-Undang Dasar Negara Republik Indonesia Tahun 1945. Terhadap notaris sebagaimana dimaksud dalam Pasal 66 Ayat (1) UU Jabatan Notaris

\footnotetext{
${ }^{24}$ Estiko, Didit Hariadi dan Suhartono. (2003). Mahkamah Konstitusi, Lembaga Negara Baru Pengawal Konstitusi. Jakarta: Pusat Pengkajian dan Pelayanan Informasi Sekretariat Jenderal DPR RI, p. 14.
} 
perlakuan yang berbeda dapat dibenarkan sepanjang perlakuan itu berkaitan dengan tindakan dalam lingkup kode etik yaitu yang berkaitan dengan sikap, tingkah laku, dan perbuatan notaris dalam melaksanakan tugas yang berhubungan dengan moralitas.

Penghapusan kewenangan pemberian persetujuan tindakan kepolisian terhadap Notaris oleh Putusan Mahkamah Konstitusi Nomor 49/PUU$\mathrm{X} / 2012$ tertanggal 28 Mei 2013, yang menghapus frasa "dengan persetujuan Majelis Pengawas Daerah" pada Pasal 66 Ayat (1) Undang-Undang Nomor 30 Tahun 2004 tentang Jabatan Notaris tidak banyak berarti dan berpengaruh terhadap pengawasan notaris karena kemudian di dalam Undang-Undang Nomor 2 Tahun 2014 tentang Perubahan Atas Undang-Undang Nomor 30 Tahun 2004 tentang Jabatan Notaris bahwa ternyata oleh pembuat UndangUndang dicantumkan kembali dalam pasal 66, di mana kewenangan yang dahulu di miliki oleh Majelis Pengawas Daerah dialihkan kepada Majelis Kehormatan Notaris yang menyatakan bahwa untuk kepentingan proses peradilan, penyidik, penuntut umum, atau hakim dengan persetujuan Majelis kehormatan Notaris berwenang mengambil fotokopi Minuta Akta dan/atau surat-surat yang dilekatkan pada Minuta Akta atau Protokol Notaris dalam penyimpanan Notaris; dan memanggil Notaris untuk hadir dalam pemeriksaan yang berkaitan dengan Akta atau Protokol Notaris yang berada dalam penyimpanan Notaris.

Pembuat Undang-Undang pada saat mencantumkan tentang kewenangan Majelis Kehormatan Notaris tidak ditunjang dengan Peraturan Menteri sesuai amanat pasal 66 A Ayat (3) Undang-Undang Nomor 2 Tahun 2014 tentang Perubahan Atas Undang-Undang Nomor 30 Tahun 2004 tentang Jabatan Notaris, yang menyatakan bahwa ketentuan lebih lanjut mengenai tugas dan fungsi, syarat dan tata cara pengangkatan dan pemberhentian, struktur organisasi, tata kerja, dan anggaran Majelis Kehormatan Notaris diatur dengan Peraturan Menteri, sehingga kewenangan yang dimiliki oleh Majelis Kehormatan Notaris tidak dapat berjalan sebagaimana mestinya, akibatnya pada saat ini terjadi kevakuman hukum terhadap pengawasan notaris yang seolah-olah terjadi situasi seperti sebelum lahirnya Undang-Undang Nomor 30 Tahun 2004 tentang Jabatan Notaris, di mana pihak kepolisian dapat langsung memanggil notaris yang bersangkutan bilamana terjadi tindakan hukum.

Pemberlakuan Pasal 66 Undang-Undang Nomor 2 Tahun 2014 tentang Jabatan Notaris, berkaitan dengan kewenangan Majelis Kehormatan Notaris berimplikasi pada belum adanya kepastian hukum terhadap notaris itu sendiri, mengingat sampai dengan saat ini belum ada peraturan turunan dari undang-undang tersebut, baik Peraturan Menterinya maupun Peraturan Pelaksanaannya. Hal ini diperkuat dengan hasil wawancara dengan M. Reza 
Berawi, ${ }^{25}$ yang menjelaskan bahwa sebaiknya pemerintah melalui Kementerian Hukum dan HAM segera memberlakukan produk hukum berupa Peraturan Menteri sebagai turunan dari Pasal 66 Undang-Undang Nomor 2 Tahun 2014 tentang Jabatan Notaris, sehingga kewenangan Majelis Kehormatan Notaris sebagaimana dimaksud, menjadi jelas dan dapat diterapkan, sehingga memberikan kepastian hukum pada tataran pelaksanaan atau implementasinya di lapangan.

Kepastian hukum merupakan asas tujuan dari hukum yang menghendaki keadilan. Menurut teori ini hukum mempunyai tugas suci dan luhur ialah keadilan dengan memberikan kepada tiap-tiap orang apa yang berhak ia terima serta memerlukan peraturan tersendiri bagi tiap-tiap kasus. Untuk terlaksananya hal tersebut, maka menurut teori ini hukum harus memuat peraturan/ketentuan umum yang diperlukan masyarakat demi kepastian hukum. Kepastian hukum sangat diperlukan untuk menjamin ketentraman dan ketertiban dalam masyarakat karena kepastian hukum (peraturan/ ketentuan umum) mempunyai sifat adanya paksaan dari luar (sanksi) dari penguasa yang bertugas mempertahankan dan membina tata tertib masyarakat dengan perantara alat- alatnya serta sifat undang- undang yang berlaku bagi siapa saja. ${ }^{26}$

Sesuai dengan ketentuan Pasal 66 Undang-Undang Nomor 2 Tahun 2014 tentang Jabatan Notaris, maka terhadap notaris yang menjalani proses peradilan proses penyidikan menjadi berbeda dibandingkan dengan warga Negara lain. Mekanisme pelaksanaan pemanggilan dan pemeriksaan terhadap Notaris oleh penyidik adalah penyidik mengajukan surat kepada Majelis Kehormatan Notaris (MKN) dengan menyebutkan untuk keperluan apa atau alasan apa sampai dilakukan pemanggilan, apakah mengambil fotokopi minuta akta dan/atau surat-surat yang dilekatkan pada minuta akta atau protokol Notaris dalam penyimpanan Notaris, atau keperluan memanggil Notaris untuk hadir dalam pemeriksaan yang berkaitan dengan minuta akta yang dibuatnya ataukah protokol Notaris yang berada dalam penyimpanan Notaris. Menjelaskan dengan kalimat yang mudah dimengerti, singkat dan jelas tentang perkara apa dan siapa tersangkanya;Setelah dalam tempo 30 (tiga puluh) hari, maka penyidik akan mendapatkan keputusan dari Majelis Kehormatan Notaris (MKN) untuk "memberikan persetujuan" atau "tidak memberikan persetujuan" atas permintaan dari penyidik tersebut

Apabila MKN memberikan persetujuan, maka penyidik akan melanjutkan dengan melakukan pemeriksaan sesuai dengan waktu yang telah ditentukanoleh penyidik. Namun apabila MKN tidak memberikan

\footnotetext{
${ }^{25}$ Hasil wawancara dengan M. Reza Berawi selaku Notaris. Selasa 19 Januari 2016.

${ }^{26}$ Rasjidi, Lili dan Rasjidi, Ira. (2001). Dasar-Dasar Filsafat dan Teori Hukum. Bandung: Citra Aditya Bakti, p. 43-44.
} 
persetujuan pemeriksaan atau menolak, maka pihak MKN harus memberikan klarifikasi dengan alasan yang sesuai dengan hukum dan ketentuan peraturan perundang-undangan. Disinilah nantinyadiprediksi akan terjadi "adu argumentasi" antara penyidik dengan MKN, karena masing-masing akan membela kepentingannya. Untuk mengatasi hal ini diharapkan masingmasing pihak untuk saling memahami dan mengerti tugas dan kewajiban masing-masing pihak demi terselenggaranya proses penyidikan. Dalam hal tempo 30 (tiga puluh) hari sejak diterimanya surat permintaan persetujuan dari penyidik kepada MKN terlampaui, maka dianggap pihak MKN telah menyetujui atas pemeriksaan terhadap Notarisdimaksud. Hal ini tidak sulit bagi penyidik untuk memutuskan memanggil kembali Notaris

Pada kenyataannya sampai dengan saat ini Majelis Kehormatan Notaris (MKN) dan Peraturan Menterinya sebagaimana diamanatkan dalam Pasal 66 dan Pasal 66 A Undang-Undang Nomor 2 Tahun 2014 belum terbentuk, demikian pula Peraturan Pelaksanaannya sebagaimana amanat pasal 91 B Undang-Undang Nomor 2 tahun 2014 tentang Jabatan Notaris juga belum ada, sehingga mekanisme penyidikan terhadap Notaris masih mengacu pada Undang-Undang Nomor 30 Tahun 2004 tentang Jabatan Notaris yang lama. Padahal Undang-Undang Nomor 30 Tahun 2004 tentang jabatan Notaris lama telah diralat dengan adanya putusan dari Mahkamah Konstitusi Nomor 49/PUU-X/2013, tanggal 28 Mei 2013 yang mencabut Pasal 66 Ayat (1), khususnya pada frasa tentangkewajiban untuk mendapatkan persetujuan dari Majelis Pengawas Daerah (MPD). Hal ini akhirnya juga berhubungan dengan tidak berlakunya lagi ketentuan dalam pasal 14 Ayat (1) Peraturan Menteri Hukum dan HAM RI Nomor M.03HT.0310, tahun 2007 yang mengatur tentang hal serupa. Dengan demikian saat ini realisasinya dalam proses pemanggilan oleh penyidik terhadap Notaris yang diduga melakukan tindak pidana, ataupun sebagai saksi biasa, maka mekanisme pemanggilannya dapat langsung kepada Notaris yang bersangkutan, tanpa melalui MPD ataupun MKN.

Seperti halnya dalam proses pemanggilan dan pemeriksaan, maka mekanisme penyitaan terhadap fotokopi minuta akta dan/atau surat-surat yang dilekatkan pada minuta akta atau protokol Notaris, di mana MKN belum terbentuk, Peraturan Menteri Hukum dan HAM belum ada serta Peraturan Pelaksanaannyapun juga belum ada, maka penyidik dapat langsung melakukan penyitaan terhadap fotokopi minuta akta dan/atau suratsurat yang dilekatkan pada minuta akta atau protokol Notaris dimaksud, sebagaimana amanat dari putusan Mahkamah Konstitusi Nomor 49/PUUX/2013, tanggal 28 Mei 2013 yang mencabut pasal 66 Ayat (1), khususnya pada frasa tentang kewajiban untuk mendapatkan persetujuan dari MPD.

Berdasarkan paparan di atas maka penulis berpandangan bahwa implikasi hukum atas pembatasan kewenangan dalam penyidikan terhadap 
Notaris terhadap proses peradilan bagi notaris adalah tidak relevan dengan persamaan warganegara di depan hukum yang seharusnya tidak membedabedakan perlakuan terhadap warganegara yang melakukan tindak pidana atau kesalahan. Selain itu persetujuan Majelis Kehormatan Notaris juga bertentangan dengan prinsip independensi dalam proses peradilan.

Aparat penegak hukum pada satu sisi dituntut untuk menjaga harkat, martabat, wibawa, dan kehormatan notaris selaku pejabat umum, dalam proses peradilan, namun pada sisi lain dituntut adanya persamaan kedudukan di hadapan hukum sebagai wujud keadilan sosial bagi seluruh rakyat Indonesia. Keadilan sosial yang berarti keadilan yang berlaku dalam masyarakat di segala bidang kehidupan, baik materiil maupun sprituil. Keadilan itu bukan keadilan formal, suatu keadilan yang lahir karena perundang-undangan, melainkan keadilan yang dikaitkan dengan habitat sosialnya yaitu masyarakat Indonesia dalam bingkai keadilan berdasarkan Ketuhanan Yang Maha Esa.Munculnya kekhawatiran dari Notaris dihapuskannya kewajiban untuk meminta persetujuan dari MPD terlebih dahulu sebelum dilakukannya pemeriksaan ataupun permintaan keterangan dari Notaris cukup beralasan meskipuin notaris masih memiliki hak istimewa berupa "Hak Ingkar". Adanya Hak Ingkar tersebut membuat Notaris sebagai jabatan kepercayaan wajib untuk menyimpan rahasia mengenai akta yang dibuatnya dan keterangan pernyataan para pihak yang diperoleh dalam pembuatan akta-akta, kecuali undang-undang memerintahkannya untuk membuka rahasia dan memberikan keterangan/ pernyataan tersebut kepada pihak yang memintanya.

Proses peradilan bagi notaris sesuai dengan ketentuan UUJN tersebut tidak relevan dengan persamaan warganegara di depan hukum yang seharusnya tidak membeda-bedakan perlakuan terhadap warganegara yang melakukan tindak pidana atau kesalahan. Persetujuan Majelis Kehormatan Notaris juga bertentangan dengan prinsip independensi dalam proses peradilan.

Notaris selaku warga negara dalam proses penegakan hukum harus diberlakukan sama dan adanya keharusan persetujuan Majelis Kehormatan Notaris bertentangan dengan prinsip independensi dalam proses peradilan dan bertentangan dengan kewajiban seorang notaris sebagai warga negara yang memiliki kedudukan sama di hadapan hukum. Dengan cara demikian akan terhindarkan pula adanya proses peradilan yang berlarut-larut yang mengakibatkan berlarut-larutnya pula upaya penegakan keadilan yang pada akhirnya justru dapat menimbulkan pengingkaran terhadap keadilan dan tidak memenuhi kepastian hukum. 


\section{Penutup}

\section{Simpulan}

Kebijakan hukum pidana terhadap pembatasan kewenangan dalam penyidikan terhadap Notaris adalah pada tahap formulasi hukum diatur kewenangan Majelis Kehormatan Notaris dalam proses peradilan terhadap notaris yaitu dengan memberikan persetujuan kepada penyidik, penuntut umum, atau hakim untuk mengambil fotokopi Minuta Akta dan/atau suratsurat yang dilekatkan pada Minuta Akta atau Protokol Notaris dalam penyimpanan Notaris. Selain itu Majelis Kehormatan Notaris berwenang memanggil Notaris untuk hadir dalam pemeriksaan yang berkaitan dengan Akta atau Protokol Notaris yang berada dalam penyimpanan Notaris.

Implikasi hukum atas pembatasan kewenangan dalam penyidikan terhadap Notaris terhadap proses peradilan bagi notaris adalah kurang sesuai dengan persamaan warganegara di depan hukum yang seharusnya tidak membeda-bedakan perlakuan terhadap warganegara yang melakukan tindak pidana atau kesalahan. Selain itu persetujuan Majelis Kehormatan Notaris juga bertentangan dengan prinsip independensi dalam proses peradilan.

\section{Saran}

Saran-saran dalam penelitian ini adalah sebagai berikut:

a. Diperlukan kebijakan hukum pidana sebagai revisi terhadap Kewenangan Majelis Kehormatan Notaris dalam proses peradilan terhadap notaris, sehingga proses penegakan hukum terhadap notaris yang melakukan suatu tindak pidana dapat berjalan sesuai dengan sistem peradilan pidana.

b. Majelis Kehormatan Notaris disarankan untuk menyerahkannya proses hukum terhadap notaris yang melakukan tindak pidana kepada aparat penegak hukum untuk menjalani proses peradilan pidana sebagai implikasi dari asas kesamaan warga negara di depan hukum sehingga tidak terdapat intervensi dalam proses penegakan hukum.

\section{Daftar Pustaka}

\section{A. Buku}

Adjie, Habib. (2009). Hukum Notaris Indonesia. Refika Aditama, Bandung. Anshori, Abdul Ghofur. (2009). Lembaga Kenotariatan Indonesia Perspektif Hukum dan Etika. Yogyakarta: UII Press.

Arief, Barda Nawawi. (2002). Bunga Rampai Kebijakan Hukum Pidana. Bandung: PT Citra Aditya Bakti.

Dewi, Santi dan Diradja, R.M Fauwas. (2011). Panduan Teori dan Praktik Notaris. Yogyakarta: Pustaka Yustisia. 
Estiko, Didit Hariadi dan Suhartono. (2003). Mahkamah Konstitusi, Lembaga Negara Baru Pengawal Konstitusi. Jakarta: Pusat Pengkajian dan Pelayanan Informasi Sekretariat Jenderal DPR RI.

Rasjidi, Lili dan Rasjidi, Ira. (2001). Dasar-Dasar Filsafat dan Teori Hukum. Bandung: Citra Aditya Bakti.

Rosidah, Nikmah. (2011). Asas-Asas Hukum Pidana. Semarang: Penerbit Pustaka Magister.

. (2014). Budaya Hukum Hakim Anak di Indonesia. Sebuah Pendekatan Hukum Progresif. Semarang: Pustaka Magister.

Saputro, Anke Dwi (Ed). (2009). Jati Diri Notaris Indonesia, Dulu, Sekarang, dan Di Masa Mendatang. Jakarta: Gramedia Pustaka.

Utama, Shidarta. (2006). Moralitas Profesi Hukum. Bandung: Refika Aditama.

\section{B. Jurnal dan Lain-Lain}

Setiawan, Wawan. (2004). "Sikap Profesionalisme Notaris dalam Pembuatan Akta Otentik, Media Notariat. Edisi Mei-Juni 2004.

Ikatan Notaris Indonesia, Kode Etik Hasil Kongres Ikatan Notaris Indonesia (INI) Tanggal 27 Januari 2005. Bandung.

Mochtar, Zainal Arifin. (2015). "Antinomi dalam Peraturan PerundangUndangan di Indonesia", Halrev Journal of Law, 1(3).

\section{Internet}

http://medianotaris.com/melawanputusanmk/berita384.html. (diakses tanggal 19 Januari 2016).

http://dilihatya.com/2411/pengertian-implikasi-menurut-para-ahli. (diakses 17 Februari 2016). 
